\title{
The passage and initial implementation of Oregon's Measure 44
}

Institute for Health Policy Studies, Department of Medicine, University of California, San

Francisco, California, USA

L K Goldman

S A Glantz

Correspondence to:

Professor SA Glantz,

Division of Cardiology, Box

0130, University of

California, San Francisco,

California 94143-0130,

USA

glantz@medicine.ucsf.edu

Received 23 December 1998 Revision received 28 April

1999

Accepted 17 May 1999

\author{
Lisa K Goldman, Stanton A Glantz
}

\begin{abstract}
Objective-To prepare a history of the passage and early implementation of Ballot Measure 44, "An Act to Support the Oregon Health Plan", and tobacco control policymaking in Oregon. Measure 44 raised cigarette taxes in Oregon by US $\$ 0.30$ per pack, and dedicated $10 \%$ of the revenues to tobacco control.
\end{abstract}

Methods-Data were gathered from interviews with members of the Committee to Support the Oregon Health Plan, Measure 44's campaign committee, as well as with state and local officials, and tobacco control advocates. Additional information was obtained from public documents, internal memoranda, and news reports. Results-Although the tobacco industry outspent Measure 44's supporters 7 to 1 , the initiative passed with $56 \%$ of the vote. Even before the election, tobacco control advocates were working to develop an implementation plan for the tobacco control programme. They mounted a successful lobbying campaign to see that the legislature did not divert tobacco control funds to other uses. They also stopped industry efforts to limit the scope of the programme. The one shortcoming of the tobacco control forces was not getting involved in planning the initiative early enough to influence the amount of money that was devoted to tobacco control. Although public health groups provided $37 \%$ of the money it cost to pass Measure 44 , only $10 \%$ of revenues were devoted to tobacco control.

Conclusions-Proactive planning and aggressive implementation can secure passage of tobacco control initiatives and see that the associated implementing legislation follows good public health practice.

(Tobacco Control 1999;8:311-322)

Keywords: advocacy, legislation, implementation, tobacco tax

\section{Introduction}

In 1996, Oregon became the fourth state (after California, ${ }^{1-3}$ Massachusetts, ${ }^{4-8}$ and Arizona ${ }^{9}{ }^{10}$ ) to enact a tobacco tax through the initiative process with a portion of the funds allocated to tobacco prevention efforts. This initiative, known as Measure 44, grew out of the need to find a stable funding source for the Oregon Health Plan (OHP). Passed by the legislature in 1989 and implemented in 1994, the OHP reformed Medicaid (a jointly funded, federal state health insurance programme for low-income and disabled individuals) in Oregon and expanded healthcare access to Oregonians who were uninsured and had low incomes. It is funded by a cigarette tax, which expires in 1999, of US $\$ 0.10$ per pack, state general funds, and the federal government.

In 1990, Oregon voters approved Measure 5, an initiative limiting property taxes, and required the state to use general funds to replace those monies lost by schools because of the lower property taxes. As with California's Proposition 13 (passed in 1978), Measure 5 led to declining general fund revenues and a tighter state budget. Because of the tight fiscal climate created by Measure 5, supporters of the OHP recognised in mid-1995 that they needed to find a better funding source for the programme than general fund revenues. This economic necessity became the impetus for an initiative known as Measure 44, "An Act to Support the Oregon Health Plan", that increased the tobacco tax by $\$ 0.30$, and dedicated $90 \%$ of the money to the Oregon Health Plan and $10 \%$ to anti-tobacco education efforts.

As it has done in every state that passed or attempted to pass ${ }^{11} 12$ a tobacco tax initiative, the tobacco industry mounted a large campaign against the measure and, after the tax passed, lobbied the legislature to prevent the funds from being spent on tobacco control programmes. Oregon's public health groups were not involved in the early phases of the tobacco tax effort, so they missed the opportunity to affect the allocation of funds. They did play an important role in the campaign to enact the tax, proactively protected the funds once they won the election, and worked effectively to see that a strong tobacco control programme was created with the available funds.

In this effort, Measure 44's supporters benefited from the experiences of California, ${ }^{1-3}$ Massachusetts, ${ }^{4-8}$ and Arizona. ${ }^{9}{ }^{10}$ All three of these states successfully passed tobacco tax initiatives, only to see the coalitions splinter in fights over money (California and Massachusetts), the money diverted to other programmes (California and Massachusetts), or the programmes themselves significantly weakened (Arizona). ${ }^{13}$ In Oregon, however, the initiative's coalition of voluntary health agencies, public health advocates, medical groups, and the Oregon Health Division (OHD) have all worked together to protect the allocation of funds and to build a strong tobacco prevention programme. ${ }^{14}$ 
Methods

We gathered information from on-the-record, taped interviews with nine Oregonians active in the campaign to pass Measure 44 or in the development and passage of the programme through the legislative process. Interviewees included three members of the Committee to Support the Oregon Health Plan (Measure 44's campaign committee), three state and local government officials involved in tobaccocontrol policymaking, two lobbyists for the voluntary health agencies, and a member of the statewide tobacco control coalition. When necessary, we asked for clarification from these individuals through electronic mail, letters, and telephone conversations. We obtained additional information from public records, internal memoranda, and news reports. A draft of a larger report dealing with tobacco control policymaking in Oregon ${ }^{15}$ that includes many of the issues discussed in this paper was distributed to eight key informants in Oregon for comments before finalising it. Their comments are reflected in this paper. No pro-tobacco representatives were interviewed for this paper.

\section{Results}

THE MEDICAL GROUPS AND THE OREGON HEALTH PLAN

In June 1995, PeaceHealth, a hospital system in Eugene, Oregon, approached the Oregon Association of Hospitals and Health Systems (OAHHS) with a proposal to sponsor a cigarette tax increase initiative on the November 1996 ballot. $^{16}$ Although PeaceHealth did not recommend an exact allocation of the funds, it advocated dedicating most of the funds to the OHP and a small amount (from $10-25 \%$ ) to tobacco prevention and education. PeaceHealth acknowledged that the tobacco prevention component was needed to gain the support of the voluntary health agencies (who would lend credibility to the campaign) and because it was a good use of the money. ${ }^{17}$

Under the proposal, OAHHS would join with the Oregon Medical Association (OMA) and Blue Cross and Blue Shield of Oregon (BC/BS) to form the executive committee of the initiative's Committee to Support the Oregon Health Plan (CSOHP). These organisations were to be the primary funders of the initiative campaign and its decision makers. As Ed Patterson, the OAHHS lobbyist, explained, "[OAHHS] believes very strongly that those who bring the gold to the table make the rules. ... [Our] basic philosophy was that three representatives from three organizations make decisions much quicker and easier and cleaner than representatives of 15 organizations." ${ }^{18} \mathrm{At}$ this crucial stage of the planning for the initiative, the public health groups and voluntary health agencies were not part of the process. Thus, these agencies had no input into the overall structure of the initiative, particularly the fraction of funds devoted to tobacco control. Measure 44 devoted $10 \%$ of the new tax to tobacco control, compared with $25 \%$ in California $^{1-3}$ and $23 \%$ in Arizona. ${ }^{9}{ }^{10}$ (The
Massachusetts constitution prevented its initiative from dedicating a specific percentage of Question 1 revenues to tobacco control, but the initiative indicates that the voters preferred that the legislature allocate the money to tobacco control efforts. ${ }^{4}$ )

In July 1995, the OAHHS board adopted the PeaceHealth proposal; OMA and BC/BS joined soon after. The executive committee (OMA, OAHHS, BC/BS, and PeaceHealth) was charged with fundraising, researching and qualifying the measure for the ballot, and managing the campaign. OAHHS, OMA, and BC/BS each committed $\$ 10000$ to hire Pacific West Communications (Pac/West), a campaign consulting firm, to conduct a poll and gauge public support for a cigarette tax increase. ${ }^{18-20}$ The poll revealed strong support for an increase in the tobacco tax of up to $\$ 0.50$ per pack.

The poll also revealed that the most popular reason for supporting the tax was "educating kids about tobacco" (75\%), while "continuing the Oregon Health Plan" also received widespread support (71\%). Reimbursing medical services providers was much less popular. In addition, the poll showed that respondents were more likely to support the tax increase if it was endorsed by the voluntary health organisations (the American Cancer Society, American Heart Association, and American Lung Association) than if it was endorsed by medical or civic groups. ${ }^{15}$ These results are similar to those found in polls in other states. ${ }^{4} 62122$

The medical groups eventually decided on a tax increase of $\$ 0.30$ per pack, an amount Paul Phillips, the president of Pac/West and a state senator who chose not to run again in 1996, thought was the highest tax acceptable, based on Pac/West's survey. ${ }^{19}$ Ninety per cent of the revenues raised were to go to the Oregon Health Plan and $10 \%$ to the tobacco use reduction account. The type of tobacco control programme to be developed was unspecified at the time. Although the Pac/West poll showed that dedicating a larger percentage to tobacco control was acceptable to voters, the medical groups wanted to get the most money they could for the OHP, while still retaining the support of the voluntary health agencies. According to Patterson:

"And we [the medical groups and Pac/West] debated whether it should be $5 \%, 10 \%$, or $20 \%$.

The coalition - the tobacco free coalition folkswanted $20 \%$, wanted to increase it. And we were reluctant to do that. Because our advice was that we probably would be generating more money for tobacco use reduction programmes than any other state had done on a per capita basis. Even at $10 \% \ldots$ probably $5 \%$ would have been adequate.

We agreed on a compromise of $10 \% \ldots$... So it was a political decision." 18

(Patterson's statement that Oregon would be generating the highest per capita expenditures for tobacco control is incorrect. Oregon's programme has the lowest per capita expenditure of the four states that had tobacco control programmes funded by tobacco tax.)

After the medical groups decided on the amount of the tax and the split between the 
Oregon Health Plan and the tobacco use reduction programme, Pac/West worked with the Oregon legislative council to draft the initiative. (The office of the legislative council is a public entity charged with drafting legislation for Members of the Oregon legislature and assisting the public in drafting initiatives.) The firm then retested some of the issues through polling and submitted the language to the state. ${ }^{19}$ In accordance with Oregon law (ORS 250.067 (I)), the attorney general reviewed the draft ballot title and submitted it to the secretary of state on 20 December $1995 .^{23}$

On 8 January 1996, the lobbyist for US Tobacco, Gary Oxley, filed a challenge to the initiative's language with the secretary of state. Oxley contended that the initiative's caption (a required short summary of the initiative's subject) did not accurately identify the subject. $\mathrm{He}$ also asserted that the result statements (a required simple statement describing the result if the measure was approved or rejected) did not mention all of the types of taxes that would be raised and that the percentage of tobacco tax proceeds going to existing programmes would be decreased. Finally, Oxley argued that the summary (a required impartial statement summarising the measure and its effects) was confusing, inflated the perception of how much the Oregon Health Plan would actually receive, and did not adequately explain the impact on current recipients of tobacco tax revenues. ${ }^{23}$

Although Oxley's challenges were filed one day after the deadline for filing comments, the secretary of state gave them to the attorney general, who is responsible for reviewing challenges to the language of ballot measures. The attorney general adopted some industrybacked changes to the caption, result statements, and summary and certified the ballot language on 17 January 1996. On 22 February 1996, the Oregon Supreme Court refused Oxley standing to challenge the initiative because he had missed the comment period deadline, ${ }^{24}$ and it dismissed his case against the attorney general's certification of the ballot measure. ${ }^{25}$ This action cleared the way for the medical groups and Measure 44 .

THE VOLUNTARY HEALTH AGENCIES AND THE TOBACCO PREVENTION PLAN

While the hospitals, physicians, and insurers were doing preliminary work on a cigarette tax increase, the voluntary health agencies and other public health groups in Oregon began meeting in mid-1995 to discuss sponsoring their own cigarette tax increase initiative because of the Legislature's failure to enact tax increases. ${ }^{26}$

For many years, the Oregon chapters of the voluntary health agencies have worked together on tobacco issues as the Oregon Health Groups on Smoking or Health (OHGOSH), jointly hiring lobbyists (Conkling Fiskum \& McCormick Inc) to represent their collective interests. In addition, the voluntary health agencies are part of a larger statewide organisation, the Tobacco-Free Coalition of Oregon (TOFCO). TOFCO is staffed by the Robert Wood Johnson Foundation's Smoke-
Less States Project and also includes various other Oregon non-profit making organisations and local public health departments. In the summer of 1995, the SmokeLess States Project brought the American Cancer Society (ACS), American Heart Association (AHA), and American Lung Association (ALA) together with Jack Nicholl, the campaign consultant for the successful California and Arizona cigarette tax initiatives, ${ }^{91021}$ to discuss a tobacco tax increase initiative. ${ }^{26}$ The voluntary health agencies and public health groups were not as well funded as the hospitals, physicians, and insurers. Nonetheless, they were committed to raising the tobacco tax to fund a tobacco education programme similar to those in California, ${ }^{1-3}$ Massachusetts, ${ }^{4-8}$ and Arizona. ${ }^{9} 10$

In late 1995 and early 1996, the voluntary health agencies and public health groups joined with the medical groups, and the Committee to Support the Oregon Health Plan (CSOHP) began its campaign for Measure 44.

Despite their common goal of passing the tobacco tax initiative, the medical groups, the voluntary health agencies, and the public health groups did not work together easily at first. According to ACS Executive Vice President Rick North, "They [the medical groups] all knew each other, you know, and had worked on political activities before. They didn't know us from Adam". ${ }^{27}$ In addition, the voluntary groups were sceptical when Paul Phillips of Pac/West asked them to join the CSOHP steering committee (an advisory committee consisting of the ACS, AHA, ALA, and other non-profit making bodies), because Phillips had introduced a bill to preempt local tobacco control ordinances in a previous legislative session. ${ }^{27}$ From the fall of 1995, when they became members of CSOHP, the voluntary health agencies and the public health groups were able to have some influence on the campaign's decision making process. They were also tasked with obtaining signatures to help qualify the initiative for the November 1996 ballot.

After the voluntaries and the public health groups assisted with the signature gathering effort and ACS contributed additional funds to the campaign (including a $\$ 43000$ contribution from national ACS and a $\$ 75000$ contribution from the National Center for TobaccoFree Kids), Rick North joined the executive committee, and the voluntary health agencies and public health groups were given a larger decision making role in the campaign. ${ }^{27} 28$

SIGNATURE GATHERING

On 11 March 1996, the secretary of state's office certified Ballot Measure 44 for signature collection. The deadline for obtaining the 73261 required signatures was 5 July 1996 . To ensure that invalid signatures and other practical problems would not keep the initiative off the ballot, the campaign actually collected 135246 signatures. Although collecting "extra" signatures is routine in initiative campaigns, it is particularly important in tobacco-related initiatives because the industry has been very aggressive in seeking to keep ini- 
tiatives off the ballot by challenging the signatures. (The tobacco industry used this strategy in Colorado ${ }^{11}$ and Arkansas to keep initiatives off the ballot.)

Pac/West hired a paid signature-gathering firm from California, Kimball Petition Management Inc., to help obtain the requisite number. (This is the same firm that Californians for Fair Business Policy, a tobacco industry front group, hired in 1991 to fight the City of Long Beach's proposal to restrict public smoking, vending machines, and billboard advertising. ${ }^{29}$ ) The ACS, the largest of the three voluntaries, took the lead in gathering signatures for the public health groups. The National ACS contributed approximately $\$ 43000$ to the ACS Oregon Division to hire a signature-gathering coordinator and to print pro- 44 brochures and signs. ${ }^{24} 2728$

Because of cool, rainy weather throughout the spring, however, the signature-gathering effort was in danger of failing. On 4 June 1996, one month before the deadline, the ACS made obtaining the requisite number of signatures a priority for the agency. ${ }^{30}$ The effort paid off: ACS collected approximately 17700 signatures of the 23770 collected by the non-profit making bodies. ${ }^{27}$ Despite some controversy about whether the paid signature gatherers were Oregon residents, Secretary of State Phil Keisling announced that he would accept the signatures from the paid gatherers. ${ }^{24}{ }^{31}$ Keisling's actions cleared the way for Measure 44 to qualify for the November ballot. ${ }^{19}$ Measure 44 was then included in the Oregon voters' pamphlet, along with supporting statements from Governor John Kitzhaber (Democrat) (a strong supporter of the Oregon Health Plan), Senator Ron Wyden (Democrat), the voluntary health agencies, the medical groups, and the public health groups. ${ }^{32}$

THE TOBACCO INDUSTRY'S CAMPAIGN AGAINST MEASURE 44

The tobacco industry began fighting the cigarette tax increase, before the measure was even certified, by challenging its language..$^{23} 25$ While signatures were being collected to qualify Measure 44 for the ballot, the tobacco industry began contributing money to a different ballot measure campaign to disrupt the signature-gathering process and to dilute support for Measure $44 .^{243}$

The proposed constitutional amendment, Measure 39, would have required healthcare insurers to cover treatment by acupuncturists, chiropractors, naturopaths, massage therapists, and other alternative (complementary) medicine practitioners. ${ }^{34}{ }^{35}$ Although the initiative was originally sponsored by these practitioners, the tobacco industry began providing financial support for the measure during the spring of 1996, when the sponsors were having difficulty obtaining the 97681 signatures needed to qualify the constitutional amendment. ${ }^{36}$ Even though Measure 39 had nothing to do with tobacco, RJR's lobbyist, Mark Nelson, explained that the industry supported Measure 39 because "We want to and will participate in proposals that may help reduce overall health care costs." ${ }^{37}$ The more likely reason was to divert the energy and financial resources of the health insurers away from Measure 44.

The tobacco industry gave $\$ 750000$ to the Measure 39 campaign to help it obtain nearly 300000 signatures, more than triple the number needed to qualify for the ballot. ${ }^{24}{ }^{38}$ This amount far surpassed the $\$ 148717$ in cash contributions and $\$ 25000$ in in-kind contributions that the official Measure 39 committee-the Health Freedoms Campaign-raised from Measure 39 supporters. This infusion of cash enabled the Measure 39 campaign to pay signature gatherers $\$ 2.25$ per signature, a significant increase over the $\$ 0.75$ that the Measure 44 campaign was paying. ${ }^{24}$ The high price allowed the industry to recruit paid signature gatherers away from the Measure 44 campaign $^{24}{ }^{33}$ and forced Measure 44's sponsors to increase the price they paid to $\$ 1.00$ per signature, costing the campaign more for signature-gathering activities than it had budgeted. ${ }^{33}$

In addition, because Measure 39 would make hospitals and physicians share healthcare dollars with alternative healthcare providers, it was natural that these groups opposed Measure 39, and devoted resources to its defeat. The tobacco industry did not contribute much money to the Measure 39 campaign after the signature-gathering phase. ${ }^{38}$ By helping Measure 39 qualify for the ballot, however, the tobacco industry was able to force Measure 44's supporters, particularly the OAHHS, to fight on two fronts, for Measure 44 and against Measure $39 .{ }^{39}$ According to $\mathrm{Ed}$ Patterson, "We were worried about our ability for our industry to generate enough money to fight Measure 37 [sic] on the one hand and then to support Measure 44 on the other hand." 18 The hospital industry donated approximately $\$ 100000$ of the $\$ 1.2$ million raised to defeat Measure 39. The insurance industry contributed the bulk of the money and took a greater interest in opposing Measure 39 than it did in supporting Measure 44 because Measure 39 more directly affected insurers. ${ }^{18}$

While the tobacco industry was contributing money to Measure 39, it was spending even more time and money fighting Measure 44. In July, the industry formed and registered a campaign committee, Fairness Matters to Oregonians Committee (FMOC), which consisted solely of RJ Reynolds lobbyist Mark Nelson and his partner, Bill Linden. ${ }^{40}$ Of the $\$ 4614292$ in cash contributed to FMOC to fight for Measure 39 and against Measure 44, all but $\$ 30$ came from the Tobacco Institute. ${ }^{151}$ The Tobacco Institute also gave $\$ 81762$ in in-kind contributions, while Philip Morris gave $\$ 4070$ and RJ Reynolds gave $\$ 4750$ in in-kind contributions. ${ }^{15} 41$

The tobacco industry used a large percentage of this money on a radio, television, and direct mail advertising campaign. ${ }^{33}$ The advertisements began in early September, with the industry purchasing time on almost every station in the state for its seven television and seven radio advertisements. ${ }^{33}$ Measure 44 sup- 


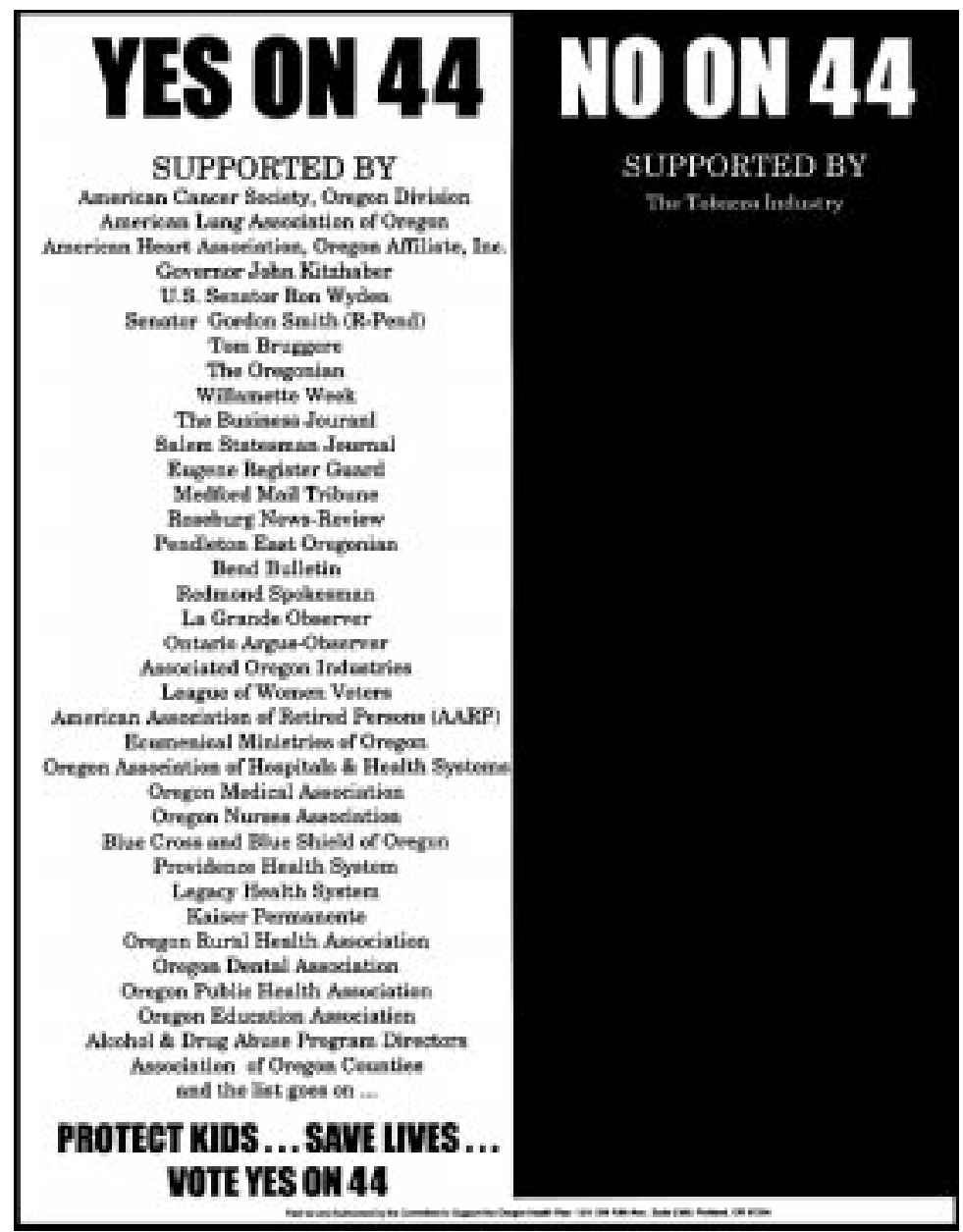

Advertisement run by proponents of Measure 44 to stress that the only opposition was coming from the tobacco industry. Note that the support of the voluntary health agencies was highlighted. funded by the existing cigarette tax, such as transportation services for the elderly and disabled. Measure 44, however, made no changes in the distribution of revenues raised by the existing cigarette tax $(\$ 0.28$ per pack permanent tax and $\$ 0.10$ per pack temporary tax), which are divided among the state general fund, cities, counties, and the Department of Transportation. ${ }^{44}$

As in other states, ${ }^{1-4} 6910$ the final theme the industry used was that healthcare providers and insurance companies were being greedy and would use the cigarette tax money to line their pockets. As one advertisement warned, "Now, Measure 44 may be a good investment for insurance companies, but it's a pretty raw deal for the rest of us." 45

The Committee to Save the Oregon Health Plan countered these advertisements by emphasising that the initiative was supported by the voluntary health agencies (ACS, ALA, AHA). As polling had shown the previous year, these three organisations had the highest level of voter support in Oregon..$^{20}$ In addition, ACS developed and paid for a print advertisement in the The Oregonian in the last week of the campaign listing the people and organisations that supported Measure 44 on one side, and the tobacco industry as the only opposition on the other side ${ }^{46}$ (figure).

The CSOHP also benefited from a favourable Federal Communications Commission (FCC) ruling against the industry on 29 October 1996, which required the tobacco industry to include the fact that it was financing the "No" campaign in its television and radio advertisements. According to Section 317 of the Federal Communications Act, television and radio stations are required to properly identify the sponsors of paid political broadcasts. ${ }^{47}$ All the "No on 44 " advertisements identified the Fairness Matters to Oregonians Committee as the sponsor, with no mention of the tobacco industry, despite the financial support that the industry provided. ${ }^{47}$ In late September, Americans for Nonsmokers' Rights (ANR), a national tobacco control advocacy organisation that had been successful in several election battles against the tobacco industry, suggested that CSOHP file an FCC complaint against the "No on 44" advertisements to force the broadcasters to reveal the tobacco industry's sponsorship. This strategy had been used with success in California. ${ }^{348} 49$ ANR recommended that the Measure 44 sponsors contact the public interest law firm and advocacy group Media Access Project (MAP), which had assisted them in California, about filing a complaint against Oregon stations. ${ }^{49}$

CSOHP was reluctant at first to file the complaint because it had developed good relationships with the stations, ${ }^{49}$ but the committee finally decided that these relationships were less important than ensuring that the tobacco industry's role in opposing Measure 44 was identified, as the advertisements were cutting into Measure 44's lead in the polls. CSOHP then provided MAP with copies of the radio and television advertisements, newspaper arti- enable the legislature to cut the amount of money going to programmes that were being
The tobacco industry used several of the used in California, ${ }^{21}{ }^{2}$ Massachusetts, ${ }^{46}$ and advertisements argued that taxing smokers to pay for health care for everyone is unfair. that Measure 44 contained no controls on general fund for the legislature to spend any way it wants, with no limits on bureaucracy and no restraints on waste. The Measure 44 machine is out of control." ${ }^{43}$ The advertisements also contended that Measure 44 would 
cles about the industry's connection to FMOC, and the contributions and expenditure reports showing that the tobacco industry was virtually the only contributor to FMOC. ${ }^{49}$

On 18 October 1996, MAP, on behalf of CSOHP, filed a complaint with the FCC against five radio and five television stations in Oregon..$^{50}$ These stations were chosen because they had the largest audience share in their market. ${ }^{49}$ The complaint asked the FCC to issue an emergency order to force the television and radio stations to comply with section 317 of the Federal Communications Act and properly identify the tobacco industry as the sponsor of the "No on 44" advertisements every time they were broadcast. On 25 October, MAP again wrote to the FCC seeking a favourable ruling on its complaint. ${ }^{51}$ On 29 October, six days before the election, the FCC ruled in favour of CSOHP and sent a letter to the broadcasters named in the complaint ordering them to comply with the ruling. ${ }^{47}$ ACS staff then called every television and radio station in the state to inform them of the FCC's ruling and ask them to comply. ${ }^{52}$ After the ruling, the industry began tagging its advertisements "Paid for by the Tobacco Institute." The ruling helped shed light on the industry's role as the sole organised opposition to Measure $44 .^{53-55}$

The tobacco industry suffered two other major setbacks, caused by its own mistakes. The first came when the industry hired former Oregon Governor Vic Atiyeh (a Republican who served from 1979 to 1987) as its spokesman. ${ }^{56}$ The tobacco industry agreed to pay Atiyeh $\$ 15000$ to appear in a television commercial opposing Measure 44 and send a letter to Oregonians urging them to oppose the initiative. ${ }^{57}$ After Atiyeh received widespread criticism of his paid opposition to Measure 44, he returned the industry's first $\$ 5000$ payment and accepted no more of its money. ${ }^{34} 58$ (The industry later listed the returned payment as an in-kind contribution from Atiyeh on its contributions and expenditures report. ${ }^{41}$ ) The tobacco industry's use of a trusted public figure as a spokesperson is not new; it tried the same strategy in Massachusetts in $1992 . .^{42}$ In both instances, however, the strategy backfired. As a columnist for the Eugene Register-Guard explained, "How valuable will [Atiyeh's] opinion be, now that the public knows it's for sale?"59

The tobacco industry suffered its second setback after sending a letter opposing Measure 44 to Oregon voters. ${ }^{60}$ The letter was signed by Dr Gene Kutsch, an Albany dentist, who was convicted in 1995 of 84 felony counts of Medicaid fraud, ordered to pay a $\$ 27500$ fine and $\$ 9041$ in restitution, and placed on probation for two years. ${ }^{60}$ In 1987 the Oregon Board of Dentistry suspended Kutsch's license for three months and restricted it for almost five years because he had prescribed controlled drugs outside his practice, for himself and several family members. ${ }^{60}$ Kutsch's legal problems, and his connection to the tobacco industry's opposition to Measure 44, received widespread coverage in newspapers in Portland, Salem, and Bend, Oregon..$^{60-62}$

SUCCESSES IN THE MEASURE 44 CAMPAIGN

When Paul Phillips of Pac/West developed the strategy for Measure 44, he decided that one of the main themes of the campaign would be exposing the tobacco industry and its tactics to capitalise on the "cynicism of the nation" towards the industry. ${ }^{19}$ One reason CSOHP was so successful in exposing the industry's activities was a Pac/West employee and Measure 44 campaign manager, Chip Terhune. Because Terhune had previously worked for Mark Nelson, the RJ Reynolds lobbyist who formed the Fairness Matters to Oregonians Committee, he was able to anticipate some of the tactics the industry would use to try to defeat the initiative.

In developing the campaign plan, Phillips emphasised the importance of free media. ${ }^{19} 63$ To earn free media, CSOHP sent speakers to community events and meetings, visited newspaper editorial boards in major cities, submitted letters to the editors of newspapers statewide, and persuaded Governor Kitzhaber to visit Salem, Eugene, and Medford the day before the election to support Measure $44 .^{46}$ (Governor Kitzhaber, as a physician and as one of the authors of the Oregon Health Plan, strongly supported Measure $44 .^{64}$ ) In conjunction with filing the FCC complaint against the tobacco industry's misleading advertisements, Measure 44's supporters sent press releases to newspapers throughout the state apprising them of the complaint. The Portland Oregonian, the Eugene Register-Guard, and the Medford Mail Tribune all ran articles about the FCC action, as did the New York Times, the Wall Street fournal, and the Washington Post. $^{49}$ 53-55

In the last three months of the campaign, the groups supporting Measure 44 began working together more closely, visiting radio stations and editorial boards as a group to debate with the two tobacco lobbyists working against Measure $44 .{ }^{27}$ Because of their sheer numbers, the Measure 44 supporters were able to visit more meetings and engage in more debates and interviews than the other side could. The emphasis on earned media paid off when most of the state's newspapers supported Measure $44 .^{65}$

At the same time, the Measure 44 campaign was benefiting from the activities of the Tobacco-Free Coalition of Oregon (TOFCO), which conducted a $\$ 140650$ media campaign that highlighted the tobacco companies' tactics and tobacco prevention. ${ }^{46}$ As part of an ongoing, two-year education campaign, TOFCO commissioned an original radio advertisement that painted tobacco industry executives as drug dealers, and used an anti-industry television advertisement from Massachusetts featuring Victor Crawford, a former tobacco lobbyist who died from tobacco-related cancer. Although neither of these advertisements specifically mentioned Measure 44 (because of the RWJ restrictions on political activities), they helped raise 
statewide awareness of the tobacco issue and the tobacco industry's actions. (TOFCO's educational efforts during the campaign for Measure 44 contrast with the situation in Colorado, when the RWJ coalition sat on the sidelines while the tobacco industry defeated a similar tax proposal in $1994 .{ }^{11}$ )

During the last month of the campaign, ACS was also running three to five general anti-smoking public service announcements (PSAs) per day. ${ }^{27}$ As PSAs, they could not carry a "Yes on 44 " message. ${ }^{46}$ Nevertheless, they contributed to statewide awareness of the dangers of smoking and the need for action.

Although TOFCO and ACS were running anti-smoking advertisements throughout October, CSOHP did not have enough money to begin its paid media campaign until the last three weeks before the election. CSOHP reserved $\$ 350000$ to produce one hard-hitting television advertisement and run it in the Portland, Eugene, and Medford television markets. ${ }^{46}$ The advertisement emphasised the hazards of tobacco use, the tobacco industry's deceptive and manipulative actions, and that the money raised by the initiative would be used for the Oregon Health Plan. ${ }^{46}$ It received free media coverage before and after it ran, thereby increasing its reach. ${ }^{19}$ During the last two weeks of the campaign, the ACS also ran pro-44 newspaper advertisements in Portland, Eugene, and Medford. ${ }^{46}$ One of the advertisements was funded by an additional $\$ 23000$ donation from the National Center for Tobacco-Free Kids. ${ }^{46}$ According to Ed Patterson of the OAHHS, the paid media campaign was successful in its portrayal of the tobacco industry as the opposition. ${ }^{18}$

\section{DEVELOPING THE TOBACCO USE REDUCTION}

PROGRAM

Although passage of Measure 44 was not assured, the OHD (Oregon's state health department) called a meeting with Measure 44's supporters in October 1996 to discuss how it would implement the tobacco use reduction programme in the event of its passage. ${ }^{18}$ The OHD consulted with the Centers for Disease Control and Prevention (CDC) and the health departments in California, Massachusetts, and Arizona about the important elements of a tobacco programme, and it was charged by the governor's office with developing a rough budget and outline for the programme. ${ }^{66} 67$ The CDC also played an important role in getting the tobacco programme through the legislature intact, testifying in its favour before the legislature and publishing a Morbidity and Mortality Weekly Report on support for Measure 44 in early $1997 . .^{68}$

The governor had agreed that after the initiative won, he would appoint an advisory committee, consisting of representatives from designated organisations, to provide recommendations to the OHD as it developed the tobacco programme. ${ }^{667}$ The advisory committee included representatives from ACS, AHA, ALA, OAHHS, TOFCO, the Department of Education, and the governor's office. ${ }^{69}$ The decision to begin programme planning before the initiative passed represented a more proactive stance than had been demonstrated in California, ${ }^{21}$ Massachusetts, ${ }^{7}$ and Arizona ${ }^{9} 10$ where there were delays between the passage of the initiative and the planning of a tobacco use prevention programme.

Ed Patterson of the Hospital Association was critical of this process, believing it was premature to develop a programme before the election, even though his organisation was to be one of the groups on the advisory committee. ${ }^{18}$ According to Patterson, the OHD plan had been written by "zealots" as much as a year before, and adopted carte blanche by the division, even though it was a violation of Measure 44 to develop the plan without going through the administrative rules process. ${ }^{18}$ Patterson believed that the tobacco use reduction programme should fund community hospitals to work with public health departments on tobacco reduction. Patterson also believed that some of the money raised by the cigarette tax should be given to schools, to fund the teaching of anti-smoking programmes. ${ }^{18}$

The governor's advisory committee released the Oregon Statewide Tobacco Prevention Plan in March, $1997,{ }^{70}$ four months after the initiative passed. This set of recommendations addressed most of Patterson's concerns. In fact, he testified in favour of the OHD's plan before the legislature, as did the other members of the advisory committee. ${ }^{66}$

Measure 44 was expected to raise $\$ 17$ million over the first two years for the programme. According to the OHD's framework, this money was to be used to decrease tobacco use by youth; treat tobacco dependence; protect children from exposure to tobacco; protect workers and the public from secondhand smoke; and secure funding and implement state and local tobacco prevention and education programmes. ${ }^{71}$ The recommended tobacco use reduction programme included five major components.

- Local activities: community health departments working with local coalitions on community-based prevention activities (\$6.5 million over two years)

- Education: grants awarded to school districts for comprehensive school-based prevention programmes ( $\$ 2.0$ million over two years)

- Statewide communications: multi-media public awareness and education campaign, including radio and television advertisements, billboards, and public events ( $\$ 4.6$ million over two years)

- Special populations: grants awarded to special populations for prevention and education activities ( $\$ 2.8$ million over two years)

- Training and evaluation: \$1.1 million over two years. ${ }^{72}$

The programme as implemented also includes a statewide cessation helpline and an innovative and demonstration projects component. ${ }^{73}$

The tobacco use reduction programme could not be implemented without the assent of the Oregon legislature, which had to approve the programme's budget. In California ${ }^{1-3}$ and 
Massachusetts, ${ }^{57}$ but not in Arizona, ${ }^{9}{ }^{10}$ the tobacco industry had succeeded in having the legislature divert significant fractions of the money allocated by voters to tobacco control to other purposes. In Arizona, the administration restricted the programme to minors and pregnant women, which limits its effectiveness. $^{94}$ Measure 44, in contrast, requires no authorising legislation other than budget approval, and it specifically allocates $10 \%$ of the funds raised to a tobacco reduction account to fund prevention and cessation programmes. ${ }^{14}$ These positive features of Measure 44 probably helped public health advocates in Oregon avoid diversion of funds and obtain the statutory authority for a broadbased, effective tobacco control programme.

THE LEGISLATIVE PROCESS

The tobacco use reduction programme is run through the OHD's health promotion and chronic disease prevention section. The division, in turn, is part of the larger Department of Human Resources. Although the $\$ 17$ million tobacco use reduction programme was less than $7 \%$ of the OHD's $\$ 260$ million budget, it received more scrutiny than any other part of the division's budget during the Oregon legislature's 1997 session (which ran from January to August 1997). ${ }^{75}$

Although the plan was not released until March 1997, the voluntary health agencies and public health groups began lobbying the legislature early to support using the money for a strong tobacco prevention and education programme. ${ }^{76}$ They also met with the editorial boards of the largest newspapers in the state to ask them to wait for the release of the OHD plan before passing judgment. ${ }^{76}$ Even before the election, lobbyists for the voluntary health agencies held approximately 10 meetings with key House and Senate leaders to highlight the agencies' agenda for the next legislative session, which included passing the tobacco programme intact. ${ }^{76}$

The lobbyists had to convince legislators that tobacco control experts were in the process of developing a tobacco prevention plan, so legislators should refrain from making any decisions about spending the new money before the plan was complete. According to Dan Jarman of Conkling Fiskum \& McCormick (CFM), the health agencies' lobbyists, the legislators were generally supportive of waiting for the OHD to develop a programme before deciding how to spend the money, as the message that this programme was a voter mandate was well accepted. ${ }^{76}$

At the same time, the tobacco industry started to lobby legislators about how the money should be spent, hoping to weaken the anti-tobacco advertising programme and ensure that the funds would be spent where they would be least effective. ${ }^{76}$ The industry has used this strategy before in California, ${ }^{1-3}$ Massachusetts, ${ }^{7}$ and Arizona. ${ }^{9}{ }^{10}$ The voluntary health agencies and their lobbyists were aware that the industry would try to reduce, restrict, or divert the money, and they had heard that RJ Reynolds lobbyist Mark Nelson was working to give the money to the education department or to schools. ${ }^{27} 7677$ Norma Paulus, the superintendent of public instruction, was also trying to get the money sent to the Department of Education to enhance the alcohol and drug programmes in the schools. ${ }^{76}$

After the tobacco prevention plan was released, CFM sent legislators a one-page information sheet in support of the OHD's comprehensive, coordinated, and communitybased programme. The information sheet urged legislators to resist tobacco industry efforts to divert the tobacco prevention monies to other purposes. ${ }^{78} \mathrm{CFM}$ also began meeting with key players in the legislature who could help guide the programme through the budget process. $^{76}$

Early on, CFM was able to secure crucial support for the tobacco programme from the Speaker of the House, Lynn Lundquist (Republican-Powell Butte), the Senate cochairman of the Joint Ways and Means Committee, Gene Timms (RepublicanBurns), and the chairman of the Ways and Means Subcommittee on Human Resources, Representative Chuck Carpenter (RepublicanPortland). Although the House co-chair of the Joint Ways and Means Committee, Representative Bob Repine (Republican-Grants Pass), initially favoured giving the money to the Department of Education, he supported the plan once CFM and the health division met him and the plan was released. ${ }^{76}$ According to Gary Conkling of CFM, Timms and Repine realised that the money for anti-tobacco advertising was appropriate as a means of countering the tobacco industry's advertising and promotional activities, and they were helpful in getting the votes at the subcommittee level. ${ }^{77}$

Before the release of the tobacco prevention plan, the tobacco industry stepped up its lobbying and was having success in the Senate in the Ways and Means Subcommittee on Human Resources. ${ }^{77}$ The Subcommittee on Human Resources has only three Senate members, John Lim (Republican-Gresham), Lenn Hannon (Republican-Ashland), and Mae Yih (Democrat-Albany). The OHD's budget had to be approved by this subcommittee before it could be considered by the full Joint Ways and Means Committee and by each chamber. Unless at least two of these three senators voted for the tobacco prevention programme, it would die without ever reaching the Senate or the House of Representatives.

The tobacco industry was able to convince two of the three senators, Hannon and Yih, to support its agenda, which included diverting the money to other programmes and ensuring that the media programme did not attack the tobacco industry. ${ }^{77}$ This situation created a "kind of knot hole politics" in which just two Senators were able to "become a majority for the entire Legislature on spending this money" ${ }^{77}$ This tactic is typically used by unpopular industries and supporters of unpopular causes to achieve their legislative goals and is one the tobacco industry has used successfully in other states. ${ }^{1-3}$ 
CFM knew from the outset that they would not be able to secure Senator Hannon's vote. ${ }^{76}$ A smoker, he accepted $\$ 2700$ in campaign contributions from the tobacco industry during the period 1985-1994. (In addition, Hannon, receiving $\$ 1000$, was one of the top recipients of tobacco money during the 19931994 electoral cycle, the last time the industry contributed to legislative candidates in Oregon. Only three members of the 1997-1998 legislature received more money from the tobacco industry during the period 1985-1994. ${ }^{15}$ In several states, legislators who accept large contributions from the tobacco industry have been shown to tend to support the industry on policy issues. ${ }^{79}{ }^{80}$ ) Senator Hannon's primary concern with the programme was the media campaign's reliance on industry bashing. He did not want to see taxpayer money spent for this purpose. ${ }^{77}$ (In California, the tobacco industry and public officials worked to soften the Proposition 99 media campaign, which early on had aggressively and effectively attacked the tobacco industry. ${ }^{81}{ }^{82}$ )

On 8 May 1997, Senator Yih sent the members of the Joint Ways and Means Subcommittee on Human Resources her six point plan for how to spend the tobacco use reduction money. Yih's plan included the idea favoured by the tobacco industry of spending $25 \%$ of the money on "prevention or reduction of tobacco use by pregnant women." ${ }^{\text {" } 3}$ Her reasoning was that spending tobacco control money on pregnant women was like getting two for one-the money would help both the mother and the unborn child. The tobacco industry has used this tactic before. ${ }^{2}$ Although there is nothing wrong with including smoking prevention activities for pregnant women in a larger tobacco control programme, concentrating on this audience reduces overall programme effectiveness because, at any given time, there are very few pregnant women.

Yih also tried to reduce the number of $\mathrm{OHD}$ tobacco reduction programme employees from seven fulltime equivalent staff positions to five. Preventing adequate staffing to run an effective programme is a strategy that the tobacco industry may have used in Arizona ${ }^{9}$ to hamper programme effectiveness. In addition, Yih tried to get a percentage of the money spent on law enforcement (another tobacco industry favourite) rather than on prevention.

CFM, staff from the health division, Rick North of the ACS, and even Yih's own son (a cardiologist in Pennsylvania), lobbied Yih to accept the OHD's proposal. Senator Timms also leaned on Yih, and she did, eventually, vote for the OHD's plan. ${ }^{76}$ Senator Hannon left the room just before the vote so he would not have to be on record one way or the other. ${ }^{27}$ After Yih acquiesced, the tobacco prevention plan developed by the OHD passed the full Joint Ways and Means Committee and both chambers of the Legislature intact. The OHD was granted its requested seven fulltime equivalent positions, and the media component of the programme was approved as drafted by the OHD in consultation with the
CDC and the public health community. These actions represented a victory for public health forces over the tobacco industry.

IMPLEMENTING THE TOBACCO PREVENTION AND PROGRAMME

In developing its tobacco programme, Oregon benefited from the experience of the three states (California, Massachusetts, and Arizona) that had implemented similar programmes. ${ }^{75}$ Accordingly, when the OHD issued its Request for Proposals for community-based programmes ${ }^{84}$ in September 1997, it distributed a "toolkit" of best practices in four intervention areas: reducing youth access to tobacco, creating tobacco-free environments, decreasing tobacco advertising and promotion, and promoting linkage to smoking cessation resources. ${ }^{85}$ Within these four intervention areas, the toolkit suggested activities for assessment and ongoing surveillance, community action, voluntary policies, and development and enforcement of local tobacco control ordinances. Suggested ordinances include licensing tobacco retailers, prohibiting self-service tobacco sales, creating smoke-free workplaces and public places, and restricting the placement of tobacco billboards. $^{84} 85$ The more populous counties are expected to develop initiatives in all four of the intervention areas, whereas the middle-sized counties are expected to address three of the areas and the smaller counties are required to address two of the intervention areas.

In September 1997, the OHD issued the Request for Proposals for the Statewide Awareness and Education Campaign ${ }^{86}$ focusing on four messages: "1) the importance and value of tobacco prevention; 2) the dangers of tobacco use; 3) the harm of secondhand smoke; and 4) the benefits of cessation" ${ }^{86}$ The OHD awarded a $\$ 4$ million contract to the Oregon Tobacco Prevention Alliance for media and public relations activities in January 1998, and the campaign began in March 1998. It concluded in June $1999 .^{87}$

In early 1999, the OHD released its first biennial report on the tobacco programme. The report noted significant progress in implementing the elements of the tobacco programme. For instance, all 36 Oregon counties had created tobacco-free coalitions, and 24 school projects reaching more than 170000 students are implementing tobacco prevention and education programmes. By the summer of $1998,75 \%$ of adults and $84 \%$ of teens in Oregon could recall seeing state-funded anti-tobacco advertisements, while the statewide quitline is up and running, helping 1500 Oregonians in January 1999 alone. Oregon is also reaching out to its special populations: all nine Native American tribes receive funds for tobacco prevention and education, and five organisations serving Hispanic, Asian/ Pacific Islander, and African American populations are implementing state-funded programmes. The state is also funding five innovative and demonstration projects focusing on such areas as cessation among pregnant women and adolescents and the provision of cessation services within healthcare systems. ${ }^{73}$ 
The end result was an $11 \%$ decline in per capita cigarette consumption in Oregon since 1996 and a decline of 35000 in the number of Oregonians who smoke. ${ }^{738}$

\section{Comment}

The tobacco industry's tactical errors in fighting Measure 44, and the ability of the Committee to Support the Oregon Health Plan to exploit those errors contributed to the initiative's passage. But CSOHP also had many of its own successes. Despite being outspent more than 7 to $1,{ }^{15}$ Measure 44 passed with $56 \%$ of the vote on 5 November 1996. This victory can be attributed to Pac/West's strategy of making the tobacco industry the issue, the emphasis on earned media, and grassroots support for the initiative.

The campaign exploited every mistake the industry made by promoting stories on former governor Vic Atiyeh, the dentist convicted of Medicaid fraud, and the FCC challenge to state and national media. ${ }^{46}$ The campaign repeatedly emphasised that the Fairness Matters to Oregonians Committee was funded almost entirely by the tobacco industry and consisted of just two people, both industry lobbyists. Keeping the already unpopular tobacco industry in the spotlight helped defuse opposition to Measure 44 .

In hindsight, the tobacco industry recognised that a campaign run solely by the industry was a mistake. As one internal memo found in the Philip Morris files noted:

"While we used third party credibility with the former Governor in our advertising and direct mail, our sole campaign spokesperson was the 'Marlboro Man' (re: Mark Nelson). Instead of benefiting from third party involvement, every press story on the campaign included quotes from the Tobacco Lobbyist as the official campaign voice. We were unable to create an atmosphere with persuadable voters to show that they were in good company in opposition to the measure." 90

The Measure 44 campaign also benefited from earned media, which was crucial as a money shortage persisted throughout the campaign. ${ }^{27}$ Every previous cigarette tax increase initiative campaign in the country ${ }^{1-1122}$ had been hampered by money problems, and such problems were expected in Oregon as well. ${ }^{27}$ Although the tobacco industry was able to begin its advertising campaign against the initiative in early September, the "Yes on 44" advertisements did not begin until late in the campaign, after some of the early support for the initiative had eroded..$^{91}$ The campaign was fortunate to have TOFCO-funded antismoking advertisements and ACS public service announcements on the air during this time, but these advertisements could not be tagged with the "Yes on 44" line. If CSOHP had been more successful in its fundraising throughout the year, it could have begun its television advertisements earlier, run radio advertisements, and sent out direct mail pieces.

Despite the successes, there is an important lesson to be learned from the Measure 44 experience: voluntary health agencies need to be more aggressive in fighting for a larger share of the cigarette tax money. Only $10 \%$ of the revenues raised by Measure 44 go to the tobacco use reduction programme, despite the fact that the voluntary health agencies contributed $37 \%$ of the funds to the campaign. In fact, although a representative from the voluntary health agencies was not allowed to join the executive committee until late in the campaign on the theory that those who contribute the money should make the rules, the voluntary health agencies gave a total of $\$ 206684$ out of the $\$ 553963$ spent. Not only were the voluntary health agencies able to give more in cash and in-kind contributions than expected, but they came through at crucial times. When the campaign needed money close to election time to run print advertisements, for instance, the National Center for Tobacco-Free Kids donated money to the ACS for that purpose. ${ }^{91}$ In addition, the voluntary health agencies lent crucial credibility to the campaign. Without their active support, the medical groups would have had difficulty countering industry charges that doctors and hospitals were just trying to line their pockets.

This pattern - in which voluntary health agencies provide credibility and last-minute financial support to tobacco tax initiative campaigns, yet reap smaller gains for funding of their priority public health programmes-is one that has been seen in California ${ }^{321}$ and Massachusetts. ${ }^{4}$ Public health groups in states contemplating cigarette tax increases should recognise that unless they become more aggressive in fighting for a sufficient share of the revenues, they will be left with less money than they deserve and than the public health warrants.

In the other states with tobacco tax initiatives (California, Massachusetts, and Arizona), the tobacco industry was able to weaken the tobacco prevention programmes either in the legislature or via the administration. Oregon, however, was able to learn from these states and avoid many of the problems that have plagued those tobacco control programmes. For instance, although the major players who passed the initiative have not historically been natural allies, they worked together during the legislative session to ensure that the money was spent appropriately. This contrasts particularly with California, where the physicians and hospitals (with the strong support of the tobacco industry) have pushed to divert money away from tobacco prevention and education, despite their support for Proposition 99 during the campaign. ${ }^{21}$ In addition, in Oregon the voluntary health agencies insisted that the funds be spent as required in the initiative, whereas public health groups in California ${ }^{23}$ and, initially, Massachusetts ${ }^{7}$ accepted the diversion of funds away from tobacco control as a necessary compromise.

Measure 44 also profited from Governor John Kitzhaber's strong support for the initiative. As a physician and as one of the authors of the Oregon Health Plan, Kitzhaber believed in the twin goals of Measure 44 - providing a revenue stream for the Oregon Health Plan and funding an effective tobacco 
control programme. Kitzhaber wrote a statement supporting Measure 44 for the voter's guide, and he made campaign appearances on behalf of the initiative. He also appointed tobacco control advocates to serve on the Tobacco Reduction Advisory Committee he formed by executive order. Most importantly, though, neither Kitzhaber nor members of his administration interfered with the OHD's programme planning and implementation of Measure 44. In California, in contrast, Governor Wilson and his political appointees have routinely diluted Proposition 99 by diverting the funds from tobacco control and placing restrictions on the media campaign. ${ }^{3}$

Finally, the voluntary health agencies knew that the tobacco industry would try to divert the Measure 44 money to less effective programmes such as law enforcement and school-based alcohol and drug education. Anticipating this, the voluntary bodies and their lobbyists went to key legislators early and explained to them why such programmes are ineffective and why they should wait for the OHD to develop a programme before deciding how to spend the Measure 44 money. When the OHD was developing its tobacco reduction programme, it was able to structure the programme like those in California, Massachusetts, and Arizona, and use their successful outcomes as proof that such approaches are effective.

The public health community in Oregon beat the tobacco industry at the ballot box and in the legislature. They were successful, in part, because they learned from the other states with tobacco tax initiatives to avoid early (and difficult to reverse) compromises with the industry and its political allies in the beginning phases of programme implementation.

This work was supported by NCI Grant CA-61021.

1 Balbach E, Monardi F, Fox B, et al. Holding government accountable: tobacco policy making in California, 1995-1997. accountable: tobacco policy making in California, 1995-1997. San Francisco, California: Institute for Health Policy
Studies, University of California San Francisco, June Studies,
1997.

2 Monardi FM, Balbach ED, Aguinaga S, et al. Shifting allegiances: tobacco industry political expenditures in California, 7anuary 1995-March 1996. San Francisco, California: Institute for Health Policy Studies, University of California San Francisco, April 1996.

3 Glantz S, Balbach E. California tobacco wars. Berkeley, California: University of California, 1999.

4 Koh HK. An analysis of the successful 1992 Massachusetts tobacco tax initiative. Tobacco Control 1996;5:220-5.

5 Begay M, Glantz S. Question 1 tobacco education outlays from the 1994 fiscal year to the 1996 fiscal year. Amherst, Massachusetts: University of Massachusetts School of Public Health and Health Sciences, August 1995.

6 Begay M. The campaign to raise the tobacco tax in Massachusetts. Am F Public Health 1997;87:968-73.

7 Begay M, Glantz S. Question 1 tobacco education expenditures in Massachusetts, USA. Tobacco Control 1997;6:21318.

8 Heiser PF, Begay ME. The campaign to raise the tobacco tax in Massachusetts. Am F Public Health 1997;87:968-73.

9 Bialous SA. Tobacco control in Arizona, 1973-1997: report. San Francisco, California: Institute for Health Policy Studies, University of California San Francisco, October 1997

10 Bialous SA, Glantz SA. Arizona's tobacco control initiative illustrates the need for continuing oversight by tobacco control advocates. Tobacco Control 1999;8:141-51.

11 Monardi FM, O’Neill A, Glantz SA. Tobacco industry political activity in Colorado 1979-1995. San Francisco: Institute for Health Policy Studies, University of California, San Francisco, May 1996.

12 Moon RW, McFarland MB, Males M. Failed tobacco tax plan offers valuable lessons. Chron Dis Notes Rep 1991(Summer/Fall):14-16.
13 Pierce-Lavin C, Geller A. Creating statewide tobacco control programs after passage fo a tobacco tax. Cancer Supp 1998;83:2659-65.

14 North R. Getting key players to work together and defending against diversion-Oregon. Cancer Supp 1998; 83:2713-16.

15 Goldman LK, Glantz SA. Industry political expenditures and tobacco policy making in Oregon: 1985-1997. San Francisco: Institute for Health Policy Studies, University of California at San Francisco, June 1998. www.library.ucsf.edu/tobacco/or/ (accessed Aug 1999).

16 Roberts C. Oregon Association of Hospitals and Health Systems. Letter to K Routledge, 27 June 1995.

17 PeaceHealth. Tobacco tax initiative summary. Fact sheet published by PeaceHealth, Eugene, Oregon, 1995.

18 Patterson E. Oregon Association of Hospitals and Health Systems. Interview with LKG, 8 September 1997.

19 Phillips P. Pacific West Communications. Interview with LKG, 4 September 1997.

20 Pacific West Communications Group I. Oregon Tobacco Tax Coalition statewide survey: poll. Portland, Oregon: Pacific West Communications Group, 1995.

21 Traynor MP, Glantz SA. California's tobacco tax initiative: the development and passage of Proposition 99. F Health Polit Pol Law 1996;21:543-85.

22 Ross M. Tobacco tax campaigns: a case study of two states. Washington, DC: Advocacy Institute, 1996.

23 Rocklin RB. Office of the State Attorney General. Letter to C Sealock, Director, Elections Division, 17 January 1996.

24 Weller J. Volunteer signature drive. In: The 1996 Oregon tobacco tax initiative: a history of the campaign. Portland, Oregon: American Cancer Society Oregon Division, 1996.

25 DiLorenzo JJ of Hagen, Dye, Hirschy and DiLorenzo. Memo to Senator P Phillips, 23 February 1996.

26 North R. Coalition efforts. In: The 1996 Oregon tobacco tax initiative: a history of the campaign. Portland, Oregon: American Cancer Society Oregon Division, 1996.

27 North R. American Cancer Society Oregon Division. Interview with LKG, 3 September 1997.

28 North R. American Cancer Society Oregon Division. Letter to LKG, 19 March 1998.

29 Traynor MP, Begay ME, Glantz SA. New tobacco industry strategy to prevent local tobacco control. $7 A M A$ 1993; 270:479-86.

30 North R. Memorandum to all staff re: tobacco tax situation. Portland, Oregon: American Cancer Society Oregon Division, 4 June 1996 .

31 Hill GK. State investigates signature-gatherers. The Oregonian $1996 \mathrm{Jul}$ 4:A1.

32 Keisling P. Official 1996 general election voters' pamphletstatewide measures. Salem, Oregon: Oregon Secretary of State, 1996:181-199.

33 Weller J. Tobacco industry opposition. In: The 1996 Oregon tobacco tax initiative: a history of the campaign. Portland, Oregon: American Cancer Society Oregon Division, 1996.

34 O'Neill P. Atiyeh returns $\$ 5,000$ to cigarette tax opponents. The Oregonian 1996 Sep 13:A1.

35 O'Neill P. It's a burning issue to big medicine, tobacco. The Oregonian 1996 Sep 27:A1.

36 Collins C. Gearing up for taxing times. Portland (Oregon) Physician Scribe 1996 Sep 5:1

37 Law S. Smoke and ballot measures. Business fournal 1996 May 3:1.

38 Noah T. Election unites acupuncturists, tobacco lobby. Wall Street fournal 1996 Oct 29:B1.

39 Law S. Ballot measures spur TV advertising blitz. Business fournal 1996 Sep 13:1.

40 Fritsch J. US is asked to tell group to disclose tobacco ties. New York Times 1996 Oct 19:7.

41 Keisling P. Summary report of campaign contributions and expenditures, general election, November 5, 1996. Salem, Oxpenditures, general election, November 5, 1996. Sal

42 Associated Press. Media blitz burns tobacco tax support. Oregon tobacco tax initiative: 1996 Oct 13:6D.

43 Fairness Matters to Oregonians Committee. Anti-Measure 44 advertisement-government waste, 1996.

44 Gallant S, Speight B, Linden B, et al. Explanatory statement, measure no. 44. In: Official 1996 general election voters' pamphlet-statewide measures. Salem, Oregon: Oregon Secretary of State, 1996:183.

45 Fairness Matters to Oregonians Committee. Anti-Measure 44 advertisement-insurance companies, 1996

46 Riger LA. Paid and earned media. In: The 1996 Oregon tobacco tax initiative: a history of the campaign. Portland, Oregon: American Cancer Society Oregon Division, 1996.

47 Stewart RJ. Letter to radio and television station licensees. Federal Communications Commission, 29 October 1996.

48 Macdonald H, Aguinaga S, Glantz SA. The defeat of Philip Morris's Proposition 188 in California. Am F Public Health 1997;87:1989-96.

49 Weller J. Federal Communications Commission Complaint. In: The 1996 Oregon tobacco tax initiative: a history of the campaign. Portland, Oregon: American Cancer Society Oregon Division, 1996.

50 Fritsch J. US is asked to tell group to disclose tobacco ties. New York Times 1996 Oct 19:7.

51 Sohn GB, Schwartzman AJ, Paykel JS. Consolidated reply of the Committee to Support the Oregon Health Plan. Media Access Project, 25 Oct 1996.

52 North R. American Cancer Society Oregon Division. Email to LKG, 5 May 1998.

53 O'Neill P. Tobacco industry must put stamp on ads. The Oregonian 1996 Oct 30 
54 Dow Jones News Services. Oregon broadcasters must disclose role of tobacco firms in ad. Wall Street fournal disclose role

55 Schwartz J. FCC orders disclosure of ads' sponsor. Washington Post 1996:A15.

56 O'Neill P. Tobacco industry hires Atiyeh to fight cigarette tax. The Oregonian 1996 Sep 11.

57 Atiyeh V. Fairness Matters to Oregonians Committee. Letter to The Oregonian. September 1996.

58 Associated Press. Atiyeh gives tobacco money back. The Bulletin (Salem, Oregon) 1996 Sep 13:B3.

59 Bishoff D. Check burned Atiyeh's image. The (Eugene, Oregon) Register-Guard 1996 Sep 13.

60 Green AS. Tobacco tax opponents burn their fingers again. The Oregonian 1996 Oct 18:A1.

61 Associated Press. Tax-hike foe has fraud conviction. The Bulletin (Salem, Oregon) 1996 Oct 18:B3.

62 Blankenbaker R. Tobacco tax embroils lobbyist. Statesman fournal (Bend, Oregon) 1996 Oct 18

63 Committee to Support the Oregon Health Plan. Earned Media Plan: the Act to support the Oregon Health Plan (memo). Portland, Oregon: Pacific West Communications, undated.

64 Kitzhaber JA. Argument in favor, Measure No. 44. In: Official 1996 general election voters'pamplet-statewide measures. Salem, Oregon: Oregon Secretary of State, 1996:192.

65 North R. Why we won. In: The 1996 Oregon tobacco tax initiative: a history of the campaign. Portland, Oregon: American Cancer Society Oregon Division, 1996.

66 Niblock B. Tobacco-Free Coalition of Oregon. Interview with LKG, 9 September 1997.

67 Moore JM. Designing an effective statewide tobacco control program-Oregon. Cancer Supp 1998;83:2733-5.

68 US Centers of Disease Control and Prevention. Tobacco tax initiative-Oregon, 1996. MMWR 1997;46:246-8.

69 Widerburg B. Tobacco Reduction Advisory Committee appointed. Press release, Department of Human Reappointed. Press release,

70 Widerburg B. Tobacco Reduction Plan presented to Governor Kitzhaber. Press release, Oregon Health Division 20 nor Kitzhaber.

71 Tobacco-Free Coalition of Oregon. Oregon Statewide Tobacco Prevention Plan. Portland, Oregon: Tobacco-Free CoaliPrevention Plan. Portland, Oreg

72 Oregon Health Division. Tobacco Prevention and Education Program description and budget. Portland, Oregon: Oregon Health Division, July 1997.

73 Oregon Health Division. Tobacco Prevention and Education Program report-1999. Portland, Oregon: Oregon Health Division, Department of Human Resources, February 1999

74 Glantz SA. Preventing tobacco use-the youth access trap (editorial). Am f Public Health 1996;86:156-8.
75 Sievers M. Oregon Health Division-Health promotion and chronic disease prevention. Interview with LKG, $5 \mathrm{Sep}$ 1997.

76 Jarman D. Conkling Fiskum and McCormick Inc. Interview with LKG, 3 Sep 1997.

77 Conkling G. Conkling Fiskum and McCormick Inc, 3 September 1997

78 Jarman D, Conkling G. Tobacco use reduction: making the money matter. Salem, Oregon: Oregon Health Groups on Smoking or Health, 1997.

79 Glantz SA, Begay ME. Tobacco industry campaign contributions are affecting tobacco control policymaking in California. $\mathscr{f} A M A$ 1994;272:1176-82.

80 Monardi F, Glantz SA. Are tobacco industry campaign contributions influencing state legislative behavior? Am $\mathcal{F} P u b-$ lic Health 1998;88:918-23.

81 Balbach E. Tobacco control advocates must demand high-quality media campaigns: the California experience. high-quality media campaigns: the
Tobacco Control 1998;7:397-408.

82 Malmgren KL. Memorandum to Samuel D Chilcote Jr, regarding California's anti-tobacco advertising campaign. Washington, DC: Tobacco Institute, 18 April 1990.

83 Yih M. Memorandum to Joint Ways and Means Subcommittee on Human Resources re: Tobacco Use Reduction Proposal, 8 May 1997.

84 Oregon Health Division. Request for proposals (RFP) for local coalitions and community-based programs. Portland, Oregon: Tobacco Prevention and Education Program, Oregon Health Division, 15 September 1997.

85 Oregon Health Division. Tool kit: community-based best practices to reduce tobacco use. Portland, Oregon: Tobacco Prevention and Education Program, Oregon Health Division, September 1997.

86 Oregon Health Division. Request for proposals 165 for statewide awareness and education campaign, tobacco prevention and education program. Portland, Oregon: Tobacco Prevention and Education Program, Oregon Health Division, 24 September 1997.

87 Sievers $M$. Oregon Health Division-Health Promotion and Chronic Disease Prevention. Email to LKG, 6 March 1998.

88 US Centers for Disease Control and Prevention. Decline in cigarette consumption following implementation of a comprehensive tobacco prevention and education program-Oregon, 1996-1998. MMWR 1999;48:140-3. 89 Suo S. Big-tobacco outlays nearly match record. The Oregonian 1996 Dec 6.

90 Philip Morris. Oregon post mortum. Minnesota Depository Bates 2062516365/6367, 1996.

91 North R. What we could have done better. In: The 1996 Oregon tobacco tax initiative: a history of the campaign. Portland, Oregon: American Cancer Society Oregon Division, 1996. 